\title{
PRIČEVANJA O POTOVANJIH PO BALKANSKEM POLOTOKU OD XV. DO XVII. STOLETJA: GLASBENA FOLKLORA IN LJUDSKI OBICAJI ${ }^{1}$
}

\author{
Danica Petrović (Beograd)
}

Pričujoča razprava želi na podlagi zbranih podatkov iz beležk popotnikov prikazati položaj krščanskega prebivalstva na Balkanu, predvsem pa vlogo glasbe $\mathrm{v}$ njegovem mučnem življenju pod turško oblastjo v času od XV. do začetka XVIII. stoletja. V stoletjih, ki so zahodni Evropi prinašala iz dneva $\mathrm{v}$ dan napredek na poti $\mathrm{k}$ političnim svoboščinam in intelektualni neodvisnosti, se je Balkan posebno $\mathrm{v}$ XVI. in XVII. stoletju vse bolj utapljal pod bremenom turške nadvlade.

Popotniki so kot sodobniki in očevidci mnogih dogajanj v deželah na balkanskem polotoku zabeležili zanimive podatke ne le o težkih življenjskih pogojih, ampak tudi o vitalnosti ljudstva, o njegovi borbi in želji, da se ohrani in ne pozabi svojega porekla.

Medtem ko so šle po cestah karavane krščanskih sužnjev in je zvok bobnjev in dobošev opozarjal popotnike na nevarnost razbojnikov, "so ti bedni kristjani, ki so se vračali s polja, prepevali svoje preproste hajduške pesmi».2 Petje žalostink za pokojnimi in molitve nad starimi in svežimi grobovi so se menjale $\mathrm{z}$ veselimi pesmimi in plesi na vaških praznovanjih in proščenjih. Popotniki z Zahoda, ki niso bili vajeni podobnih prizorov, so pogosto pisali o ljudeh, ki so jih srečavali ter o njihovih oblačilih in obredjih, katerim so slučajno prisostvovali, ko so šli skozi te kraje. Čeprav so včasih zelo subjektivni $\mathrm{v}$ ocenjevanju vsega, kar so videli, so ti kronisti zapustili dragocene podatke o življenju ljudstva, njegovih običajih in glasbi v XV., XVI. in XVII. stoletju.

Učeni pisec in svetnik beneške vlade Benedetto Rambert je potoval skozi Crno goro, Kuršumlijo in Toplico v Carigrad leta 1534 v misiji $D$. de Ludovicija. $\mathrm{Na}$ poti skozi Črno goro so popotniki prišli do Pljevlja, ıkjer je bila pred petimi leti razbita karavana beneških trgovcev. Proti razboj-

1 To delo je nadaljevanje razprave $\mathrm{z}$ naslovom "Pričanja o putovanjima po Balkanskom poluostrvu od XV do XVIII veka kao izvori za istoriju srpske muzike» (podaci o crkvenoj muzici), Arti Musices št. 4, 1973, 101-108.

2 Matković P.. Putovanja po Balkanskom poluostrvu XVI vieka, putopis Stephana Gerlacha (1572-73), Rad JAZU št. 116, 1892, 50. 
nikom-hajdukom so postavljali krajevne straže: po ena oseba iz kraja je šla z bobnanjem skozi gozd in ogledovala, če niso morda skriti kakšnii hudodelci; z udarjanjem na boben je dala popotnikom znak, da je prehod varen. $\|^{3}$ Podobne beležke o gozdnih stražah z bobni v okolici Jagodine, na poti od Niša do Sofije in v Larisi v Grčiji, najdemo tudi pri drugih potopiscih. ${ }^{4}$ Francoz Pierre Lescalopier, ki opisuje namesto bobnja doboš, dodaja, da so »krščanski Srbi iz Plevlja oproščeni plačevanja davščin s pogojem, da stražijo po pljevaljskih gorah. ${ }^{5}$ Po trditvah neznanega potopisca iz misije $K$. Ryma so se ob zvoku bobnarja zbirali vsi vaščani, ker so tudi oni bili pogosto žrtve whudobne drhali». Iz teh stražarjev izhajajo morda vaški bobnarji, ki še danes po nekaterih vasen Srbije in Vojvodine pozivajo $\mathrm{z}$ udarci na doboš vaščane na zbor ali posvet.

Evvlija Ċelebija piše, da so Turki po boju s kristjani mzaplenili mnogo

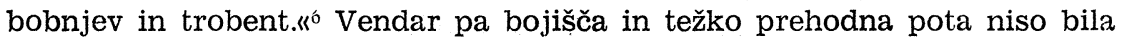
edina mesta, kjer so se slišali zvoki glasbenih instrumentov.

Angleški zdravnik Edward Brown je slišal na sejmu v Leskovcu "razno. vrstno igranje», ${ }^{7}$ medtem ko je P. Tafernier ${ }^{8}$ na poti od Niša proti Sofiji videl "tri Bolgare $\mathrm{z}$ dvema velikima in enim malim medvedom, ki so plesali ob glasbi. Za boljše razpoloženje so Bolgari igrali na cimbale in druge instrumente. ${ }^{9}$ Melchior Besolt piše, da je v Jagodini srečal ljuadi, ki so se vračali s svatbe "z zvončki, bobni in dudami.«10 Ko je Hans Dernschwam potoval proti Odrinu, je naletel na yosem bolgarskih beračev, ki so sedeli ob poti, od katerih sta dva igrala na gusle.»11 Nekaj bobnarjev in goslačev je zaigralo na čast poslanstva L. Nogarola, ko je maja 1532 zapuščalo Vrh Bosno (Sarajevo).12

Na potovanju skozi Bosno sta Francoza Nicolas de Nicolay (1551) in Jean P. Foresien (1582) srečala skupino tako imenovanih vojnukov. ${ }^{13} \mathrm{Ker}$

3 Matković P., ibidem, putopis B. Ramberta (1534), Rad JAZU, št. 55, 1881, 214.

4 Razen navedenih potopiscev so o gozdnih stražah pisali: J. Gassot (1548), Goơišnjica Nikole Čupića št. 49, 1940, 88; H. Dernschwam (1553-1555), Bratstvo št. 21, 1927, 61-62 in 67; Nepoznati putopisac iz poslanstva K. Ryma (1571), Rad JAZU št. 112, 1892, 176; P. du Fresne-Canaye (1573), Godišnjica Nikole Čupića št. $49,1940,89$.

5 Prim. Samardžić R., Beograd i Srbija u spisima francuskih savremenika, Istorijski arhiv Beograda, Beograd 1961, 135; Šmić M., Opis puta Pjera Leskalopjea kroz naše zemlje 1574. godine, Glasnik arhiva i društva arhivista BiH, III, $1963,353$.

6 Čelebija E., Putopis, Sarajevo 1954, 161.

7 Novaković S., Beleške doktora Brauna iz srpskih zemalja od godine 1669, Spomenik SKA IX, Beograd 1891, 39.

8 Pri različnih avtorjih najdemo različne variante tega potopisca, Jean B. Tavernier, Pauli Tafferneri, P. Tafernier. Domnevamo, da izhajajo te razlike iz različnih izdaj in prevodov potopisa.

9 Śšsmanov I., Stara putovanja prjez B'lgariju, Zbornik za narodni umotvorenija, nauka i knjižnina IV, Sofija 1891, 320-483.

10 Matković P., ibidem, putopis M. Besolta (1584), Rad JAZU št. 129, 1896, 61.

11 Sišmanov I., ibidem, 408.

12 Ta podatek je dal ljubeznivo na voljo Triva Militar, arhivar Matice Srpske $\mathrm{v}$ Novem Sadu.

13 "Vojnuci» so bili pripadniki posebnih pomožnih odredov v turški vojski, ki so bili sestavljeni iz vrst kristjanov, njihova dolžnost pa je bila, da so se v vojni in miru brigali za konje. Prim., R. Samardžić, ibidem, 761. 
Ker so bili ti zelo siromašni, "so izrabili pičel prost čas, ki jim je ostal od dneva, tako da so zabavali ljudstvo in si nabrali nekaj denarja. Z velikimi dudami iz kozjega meha so okrog sebe zbrali ljudi, in izvajali ob njihovem zvoku plese in poskočnice $s$ tako gibkostjo telesa in nog, da jih je bilo veselje gledati. Potem ko so se naplesali in naskakali, so dobili za miloščino kak novec, kar je bilo za njih nekaj dobička in v pomoč njihovemu uboštvu. Razen tega prirejajo ljudske zabave še na drug način. Po šest ali sedem se jih zbere in maskirani so $\mathrm{v}$ načinu vratu ali glave žerjava in različnih drugih najbolj fantastičnih živali na svetu..14

Podrobne opise glasbenih instrumentov sta dala $\mathrm{v}$ svojih potopisih Francoz A. Poullet in angleški plemič John Burbury. Poullet je leta 1658 bival v Slanem pri Dubrovniku, kjer je videl pri prebivalcih ${ }^{15}$ "vrsto glasbila, $\mathrm{ki} \mathrm{mu}$ pravijo tamburica in po obliki in velikosti spominja na lesen čevelj naših (francoskih) kmetov. Vrat je dolg tri četrtine aršina in nekaj širši kot dobra dva prsta. Na njem so napete samo tri medeninaste strune, na katere udarjajo s perescem; to pomanjkljivost lahko nadoknadijo, s pomočjo številnih tipk, ki jih uporabljajo za izvajanje akordov." To glasbilo je bilo tako popularno, sda ni bilo otroka iz dobre hiše, ki ne bi znal nanj igrati, ga ne bi imel in nosil s seboj na potovanju, v vojni, peš, na konju, zadrgnjenega na ramenih vzporedno s cevjo za pipo.»16 Po Poulletovem opisu je ta tambura podobna lirici, še danes priljubljeni v dubrovniški župi in Konavlih, le da se lirico igra $z$ lokom..$^{17} \mathrm{O}$ petju prebivalcev Slanega pravi potopisec, da je "precej v soglasju z njihovo glasbo», vendar se pritožuje, da je ta pretirano glasna in se čudi, da ni »oglušel«. Posebno piše o zniževanju glasu, katerega prebivalci izražajo z nekakšnim vzdihovanjem ob koncu vsake kitice, pri čemer se zdi kot da padajo $v$ vzhičenje«. Podobno vzklikanje je znano v ljudskem petju raznih krajev balkanskega polotoka.

Leta 1664 se je J. Burbury mudil v Beogradu v hiši "grškega trgovca" Maria Manikata. Ta veseli gostitelj je "pil kot riba in spremljajoč svoje lastno petje je udarjal na talambas... Talambas je bil velik. To je bil velik prsten sod, kot pivski bokal brez dna, čez katerega je bila napeia kot pergament tanka koža; in po tej je s svojimi prsti umetno in prijetno udarjalu.18 $\mathrm{Tu}$ je govor o instrumentu tarabuka, ki ga Arabci imenujejo darabukke, tolkalu po poreklu z Vzhoda. ${ }^{19}$ Pri nas je ta instrument najbolj

14 Samardžić R., ibidem, 117-118.

15 Ker je bil verjetno neiformiran, je Poullet mislil, da so bili prebivalci Turki. Vendar je Slano pripadalo Dubrovniški republiki in opisano glasbilo je značilno za folkloro tega kraja. Podobne napake o etnični in nacionalni pripadnosti prebivalstva najdemo tudi $\mathrm{v}$ spisih drugih popotnikov.

16 Jelović V., Doživljaji Francuza Poulleta na putu kroz Dubrovnik $i$ Bosnu 1658, Glasnik Zemaljskog muzeja BiH, 1908, 42.

17 Prim., Muzička enciklopedija II, Zagreb 1963, 111 in 695; Ivančan I., Narodni plesovi Dalmacije I, Institut za narodnu umjetnost, Zagreb 1973, 31-34.

18 Novaković S., Putničke beleške o Balkanskom poluostrvu XVII in XVIII veka, Godišnjica Nikole Čupića XVII, 1897, 79-80.

19 Potopisec ali prevajalec ni dobro poznal glasbene instrumente in je ta instrument imenoval talambas. Glede na opis je razviōno, da gre za instrument tarabuka. Talambas je po Vuku tympanum (prim. Karadžić V., Srpski rječnik, Beograd 1696, 809); sodobni etnomuzikologi menijo, da je talambas membranofon 
razširjen $\mathrm{v}$ Makedoniji. Vendar tarabuka večinoma spremlja ples in je zato čudno, da se tu omenja kot spremljava pri petju. Vprašanje je še, od kod je prišel omenjeni trgovec Manikato v Beograd. Morda je bil Grk, kot to navaja sam potopisec, vendar ne smemo pozabiti, da so ljudje z Za. hoda večkrat imenovali vse pravoslavne ljudi Grke. Glede na današnjo razširjenost tega instrumenta bi lahko domnevali, da je Manikato prišel iz Makedonije.

V posameznih krajih Srbije in Makedonije srečamo tudi danes calgije, nekake orkestre $\mathrm{z}$ instrumenti, ki so najpogosteje tambur, dair in tarabuk. Podobno skupino muzikov opisuje leta 1658 Francoz M. Quiclet, sopotnik že omenjenega A. Poulleta. Ta je v Beogradu poslušal in gledal "Cigane in Ciganke, ki plešejo in pojejo ob spremljavi svojih ćemanet (kementhe) oziroma neke vrste violine, santoura, neke vrste monokorda ${ }^{20}$ in tchigoura $^{21}$, vrste kitare $\mathrm{s}$ petimi strunami ${ }^{22}$ Po besedah potopisca "je bilo to igranje dosti prijetno«, a tudi popularno, ker so ga poslanci v času svojega bivanja $\mathrm{v}$ Beogradu imeli večkrat za zabavo«.23 Podobna ciganska glasba se je obdržala v Srbiji tudi v XVIII. stoletju, deloma pa jo je sprejelo tudi srbsko meščanstvo v XIX. stoletju, kar izpričujejo tudi zapisi Milana Milićevića. ${ }^{24}$

Quiclet je eden maloštevilnih tujih popotnikov, ki imajo razumevanje za našo narodno glasbo. Bii je navdušen nad glasbo, ki jo je poslušal na Rači na Savi, kjer so prebivalci priredili poslanstvu serenade.

"Peli so pesmi kot se pojejo tam in igrali so na dude in oboe, udarjali so na zamolkle bobne. Niso neprijetno bobnali $\mathrm{z}$ nekakšno kljukasio palico, katere konec je imel obliko jabolka, in s palico $\mathrm{v}$ levi roki nad dobošem, z neko vrsto malega kija; zvok bobna se je dovolj ujemal z njihovimi dudami, oboami in zurlami.»25 Potopisec je nedvomno poslušal dude, zurle in tapane. Takšne instrumentalne skupine so tudi danes razširjene $\mathrm{v}$ Makedoniji, in to dude in manjše zurle ob spremljavi malega tapana $\mathrm{v}$ zahodni Makedoniji. 26 Zato domnevamo, da so bili omenjeni glasbeniki v Rači iz Srednje Makedonije.

$\mathrm{Za}$ razliko od ljudske glasbe, pesmi, plesa in instrumentalne igre, je bila na Balkanu še neke vrste oficialna turška glasba, ki je spremljala predstavnike turške oblasti na potovanjih in je povzdigovala sprejeme in spremljanja tujih misij. ${ }^{27}$ Več potopiscev je slišalo in opisalo te turške

»z eno opno na medeninastem kotlu», prim., Muzička enciklopedija II, Zagreb 1963, 271.

20 Santur je arabski predhodnik cimbal. Za isti instrument uporablja C. Sachs izraz santir (prim. History of Musical Instruments, New York 1940, 258).

21 Čigur (tchigour) je vrsta tambure, ime pa je turško arabskega porekla (prim. Muzička enciklopedija II, Zagreb 1963, 695).

22 Djurić-Klajn S., Istorijski razvoj muzičke kulture u Srbiji, Beograd 1971, 28.

23 Marković M., Jedan francuski putopisac u našoj zemlji 1658. godine, Glasnik istorijskog društva u Novom Sadu, VII, 1934, 314.

24 Miličević M. Dj., Kneževina Srbija, Beograd 1876, 124.

25 Marković M., ibidem, 312; Samardžić R., ibidem, 191-192.

26 Muzička enciklopedija II, Zagreb 1963, 699.

27 Djurić-Klajn S., ibidem, 26-27. 
godbe v Carigradu, Odrinu, Lepantu, Paraćinu, Kolarih, Rači in Ostrogonu. ${ }^{28}$

Najbolj izčrpen opis turške godbe je dal potopisec Salomon Schweigger, duhovnik cesarskega poslanika J. Sinzendorfa. Na poti proti Carigradu je njuna misija leta 1576 med mestecema Grocka in Kolari srečala beograjskega "beglerbega»,29 "ki je misijo prijetno pozảravil in ūkazal, da naj godba njej na čast zaigra». Učeni Evropejec $S$. Schweigger, ki ni bil vajen takšne glasbe, pripominja nezadovoljno: "Ta glasba je blagozvočna kot da bi sodarji nabijali sode. ${ }^{30}$ Sestav in videz te instrumentalne skupine predstavlja Schweigger $\mathrm{z}$ risbo in zanimivim opisom. Prikazal je osem Turkov z različnimi instrumenti, med katerimi so po potopiščevih besedah "(F) kovinska trobenta, (C) piščali s trstenim jezičkom (Schalmei) - povsem podobne po obliki in zvoku nemški pastirski piščali -, (D) talambas, preoblečen $\mathrm{z}$ rdečim suknom, po velikosti polovico manjši od nemškega bobna, razen tega dve medeninasti plošči $(G)$, veliki kot okrogel krožnik in iste oblike kot kardinalski klobuk z dvema obročkoma zgoraj, v katera se vtaknejo prsti; te plošče udarjajo druga ob drugo, kar pa ne zveni drugače kot če se nekoliko trejo; kakor tudi instrumenti, ki jih igra ob pesmi in plesu ljudstvo, (B) kastanjete in daire in strunska glasbila, eno, (A) ki je podobno nemški cithari in na katerega so udarjali $\mathrm{s}$ peresom in drugo, ki je podobno veliki zajemalki $(\mathrm{H}) .$. Iste instrumente so uporabljali pri vojnih pohodih, svatbah in pri drugih slavjih in gostijah. Schweigger si je celo zapomnil in zapisal eno melodijo, za katero pravi, da je podobna melodiji bojnega signala. ${ }^{31}$

Turške osvojitve severno od Save in Donave so pripeljale do širjenja turškega vpliva tudi na ogrske kraje vse do Budima in Ostrogona. Melchior Besolt piše, da so Turki leta $1584 \mathrm{v}$ Ostrogonu svečano prevzeli misijo nemškega cesarja Rudolfa II., "po večerji pa jih je zabavala turška godba in dva Cigana, ki sta plesala. Drugega dne so čakali pred begovim stanovanjem Cigani, ki so, ko so šli pred poslanikom, plesali in peli ter so ga spremljali do ladje..$^{32} \mathrm{Na}$ žalost ta avtor ne navaja imen instrumentov niti njihovega opisa.

Za razliko od Schweiggerja, ki s posmehom govori o glasbi, ki jo je poslušal v Srbiji, pa Francoz Philippe du Fresne Canaye piše, da so na poti proti Odrinu srečali "sandžaka»33 $\mathrm{s}$ spremstvom, v katerem so "doboši in piščali zelo lepo odmevaliı. ${ }^{4}$

28 O oficialni turški glasbi so pisali: B. de la Broquière (1432-1433), Putovanje preko mora, Beograd 1950, 119; P. du Fresne-Canaye (1573), Godišnjica Nikole Čupića št. 49, 1940, 105; S. Schweigger (1577), Rad JAZU št. 116, 1892, 87-88; M. Besolt (1584), Rad JAZU št. 129, 1896, 51; G. Wheler (1675-1676), Godišnjica Nikole Cupića XVII, 1897, 125-126; G. C. Driesch (1719-20), Otadžbina št. 21/22, 1899, 627.

29 Upravnik beglerbegluka, administrativnih enot, na katere so Turki razdelili zavzete balkanske dežele.

30 Matković P., ibidem, putopis S. Schweiggera (1577), Rad JAZU, št. 116, $1892,39$.

31 Djurić-Klajn S., ibidem, 26-27; opomba 59, str. 171; Šišmanov I., ibid., 437.

32 Matković P., ibidem, putopis M. Besolta (1584), Rad JAZU št. 129, 1896, 51.

33 Sandžak, točneje sandžakbeg, je bil vojni in upravni starešina $v$ sandžaku, temeljni vojaški in upravni enoti Osmanskega cesarstva. 
Angleški znanstvenik George Wheler opisuje sprejem nekega paše v Lepantu (Grčija), pred katerim se je peljalo v barki wnekaj godbenikov s talambasi in zurlami, medtem ko je neki Arabec udarjal na santur (Timbale), ${ }^{35}$ glasbeni instrument čudnega zvoka».36 Podobna skupina je delovala pri ceremoniji ob priliki srečanja turškega in avstrijskega poslanika leta $1719 \mathrm{v}$ okolici Paraćina. "Na turški strani so Cigani igrali na zurle in keman ob ropotu velikih in malih bobnov, medtem ko so turški vojaki naravnost vpili in nenehoma $\mathrm{z}$ nogami teptali po zemlji:"137 $\mathrm{Ni}$ znano, ali so bili srbski kmetje naklonjeni takšni glasbi in tudi sami igrali $\mathrm{v}$ podobnih instrumentalnih skupinah. $\mathrm{V}$ beležkah iz XX. stoletja so podatki, da "Cigani igrajo na keman in zurle ter udarjajo vsi skupaj na daire«, vendar pa naš kmet une misli, da je igranje na te instrumente cigansko opravilou ${ }^{38}$ Avstrijska misija ni izražala simpatije do takšne glasbe in potopisec G. C. Driesch piše: "Prav neznosni so bili na tem potovanju tisti turški zurlaši s svojo vreščečo glasbo. « ${ }^{39}$

Iz navedenih beležk, ki vsebujejo podatke o različnih glasbenih instrumentih in njihovi rabi, zvemo, da so ljudsko in oficialno turško glasbo izvajali na zelo podobnih instrumentih. Žal potopisci ne govore o značaju same glasbe. Zanimivo je, da so ugodnejši njihovi komentarji o ljudski glasbi kot pa o tisti, ki so jo izvajale turške godbe.

Omenjeno je vsega skupaj osemnajst instrumentov. Najštevilnejša so tolkala: pet membranofonov (boben, doboš, talambas, tarabuka, tapan) in štirje idiofoni (kastanjete, daire, zvončki, činele). Od kordofonov so potopisci opazili gusle, cimbale ali santure, egede ali keman in različne tambure (čigur, lirica ...). Egede so igrali samo Cigani in to še v prvi polovici XVI. stoletja. Aerofoni instrumenti so dude, kovinske trobente, piščali s trstom, zurle ali kot so jih potopisci večkrat imenovali oboa in druge piščali brez določenega imena. Vsi ti instrumenti so znani tudi danes, morda so po obliki in velikosti spremenjeni, vendar na njih še izvajajo $\mathrm{v}$ mnogih krajih polotoka.

Tuji popotniki so zapustili tudi nekaj beležk o plesih tipa oro - srijskem kolu, hajduškem plesu, religioznem plesu dervišev in plesu prebivalcev $v$ Slanem pri Dubrovniku (lindjo).

$\mathrm{V}$ okolici stare bolgarske vasi Ovčega ali Čenga jer poljski potopisec Otvinovsky srečal "ljudstvo, ki je plesalo po srbsko pred poslanikom, vsi kar jih je bilo, so se držali drug za drugega in se vrteli naokoli z ženskami«.40 Gre vsekakor za vrsto mešanega kola, ki je po Tihomirju Djordje-

34 Dinić M., Tri francuska putopisca XVI veka o našim zemljama, Godišnjica: Nikole Čupića br. 49, 1940, 105.

35 Prim. op. št. 20.

36 Novaković S., Putničke beleške o Balkanskom poluostrvu XVII i XVIII veka, Godišnjica Nikole Čupića XVII, 1897, 125

37 Protić K., Putovanje kroz Srbiju 1719. i 1720. godine, Otadžbina št. 21, 1889, 627.

38 Prim. Djordjević T., Naš narodni život VII, Beograd 1933, 41.

39 Protić K., ibidem, 627.

40 Matković P., ibidem, putopis E. Otvinovskog (1569), Rad JAZU št. 105, $1891,154$. 
viću najstarejša oblika plesa oro. ${ }^{41}$ Podobne plese deklet na vaškem proščenju in pri spomladanskih obredjih so opisali A. Pifagetta, Steph. Gerlach, $P$. Lescalopier. 42

Podroben opis moškega, vojaškega plesa je zapustil angleški zdravnik Edward Brown. Pred svojim prihodom na Ogrsko ni Brown nikjer videl podobnega vojaškega plesa, kot ga $\mathrm{v}$ tem kraju plešejo hajduki. ॥Ti plešejo $\mathrm{z}$ golimi meči $\mathrm{v}$ rokah in mahajo in udarjajo meč ob meč; obračajo in vijejo se, poskakujoč in poklekujoč $s$ telesom, $s$ hitrimi in krepkimi gibi in pojejo pri tem po svojem taktu na grški način« ${ }^{43}$ To je znameniti hajduški ples, še danes zelo razširjen na Madžarskem, Slovaškern in Poljskem. ${ }^{44}$ Vendar je čudno, da niso podobnega plesa opazili v Srbiji, Makedoniji ali Bolgariji.

Ples dervišev, mohamedanskih verskih fanatikov, ki pripelje $\mathrm{v}$ religiozno ekstazo, so opazovali trije potopisci v Odrinu, Beogradu in na poti skozi vzhodno Srbijo.45 Janičar Konstantin Mihailović iz Ostrovice je srečal derviše na potovanju skozi Srbijo leta 1450. "Derviši vsak dan pri večerni molitvi plešejo, hodijo v krogu, si polagajo drug drugemu roko na rame, kimajo $\mathrm{z}$ glavami, poskakujejo $\mathrm{z}$ nogami in vpijejo na ves glas: La ilaha ilallah, kot da rečeš: ni Boga razen Alaha in obračajo se zelo hitro in prav tako zelo vpijejo, da se daleč sliši, kot bi lajali psi, eden debelo drugi tanko, ta ples imenujejo sama in ga imajo za veliko svetinjo in izraz pobožnosti. Ples jih tako prevzame, da teče $z$ njih voda in iz ust pena. Od velike utrujeniosti padajo drug za drugim. Potem pa, ko pridejo iz te blazne utrujenosti, gre vsak v svoj brlog. . $^{46}$

Pisali smo o prebivalcih iz okolice Dubrovnika, ki jih je slišal A. Poullet peti ob spremljavi instrumenta podobnega lirici. ${ }^{47} \mathrm{Ta}$ glasba pripelje izvajalce po besedah potopiscev do velike vzburjenosti. "Zato se ta gospoda začne gibati takoj po prvih zvokih in zanimivo jih je videti, kako drže med prsti lesene žlice, tako kot to delajo v Franciji berači z ropotuljami. Držaj teh kastanjet je tenek kot pero in dolg pol roke. Način, kako jih uporabljajo pri plesu, je v tem, da dvigujejo roke iznad glav čim više morejo in $z$ gibom prstov na desni roki ravnajo prste leve, tako da se držaji križajo in zakrivajo čelo s parom rogov. Nad glavo udarjajo isti takt kot $z$ nogami, ker je njihov način plesa neke vrste sarabanda, katero izvajaio tako, da le zelo malo premikajo levo nogo, pri čemer pa zato nenehoma gibljejo desno in se vselej vrte okoli..48 Ta ples ustreza župskemu kolu

41 Djordjević T., Srpske narodne igre, Beograd 1907, 23.

42. Prim. str. 14-15.

43 Novaković S., Beleške doktora Brauna iz srpskih zemalja od godine 1669, Spomenik SKA IX, 1891, 42.

44 Djurič-Klajn S., ibidem, 24; Wolfram R., Altformen im Tanz der Völker des Pannonischen und Karpatenraumes, Volksmusik Südosteuropas, München 1966, 127-132.

$45 \mathrm{O}$ plesu dervišev so pisali: Konstantin Mihailović iz Ostrovice, Janičarove uspomene ili turska hronika, Beograd 1966, 117; St. Gerlach, Rad JAZU št. 116, 1892, 35; neznani potopisec iz poslanstva Louisa Deshayesa (1621 in 1626), Spomenik SKA XXXVII, $1900,69$.

46 Konstantin Mihailović iz Ostrovice, ibidem.

47 Prim str. 7.

48 Jelović V., ibidem, 44. 
ali poskočnici iz Dubrovniške župe, v novejšem času pod imenom lindjo.

Zadnji del našega razpravljanja se nanaša na ljudske običaje in obrede kot so jih videli in opisali tuji popotniki.

$\mathrm{V}$ gradivu, ki smo ga zbrali, se nahajajo opisi petih različnih običajev in obredov. To so: pogrebni običaji, binkoštne zadušnice, vaško proščenje ali cerkveno opravilo po zaobljubi, kolednice ob sv. Lazarju in svatbeni običaji. Okolica Bele Palanke, Niša in Pirota spada nedvomno med tista področja, kjer je folklorna tradicija zelo dobro ohranjena. Skoro vsi potopisci so bili presenečeni nad nenavadno bogato nošo tega kraja, nad "surovim ljudskim petjem", obrednimi plesi, žalostinkami in nenavadnimi pogrebnimi običaji.

Ko so tujci potovali po carigrajski cesti, so imeli pogosto priložnost, gledati pogrebe in poslušati, kako ljudstvo žaluje za pokojnimi. Večina je o tem tudi pisala, vendar so od vseh podobnih zapisov najobširnejši opisi iz potopisa flamskega humanista Angiera Ghislaina Busbequisa in nemškega duhovnika Stephana Gerlacha. ${ }^{49}$

A. G. Busbequius je leta 1555 prisostvoval nekemu pogrebu v Jagodini: "Mrlič je ležal v cerkvi z odkritim obrazom. Poleg njega so postavili nekaj jedače, kruha, mesa in sod vina. Pokojnikova žena in hči sta tu stali oblečeni v čisto obleko; hči je imela na glavi nekakšno čepico s pavovim perjem. Zadnji dar, ki ga je žena darovala svojemu možu, je bila majhna rdeča čepica (po vsej verjetnosti fes) kot jo tu nosijo dekleta gosposkega rodu॥. Zatem potopisec opisuje žalovanje na grobu in pravi: "Poslušali smo njihove žalostinke, kako $\mathrm{z}$ žalostnim glasom vprašujejo pokojnika: ,Kaj smo ti žalega storile, da si tako z nami napravil? Ali te nismo kaj ubogale? Kaj ti nismo po volji storile, da nas tako puščaš $\mathrm{v}$ bedi in se moramo same hraniti?' In še mnogo drugega temu podobnega.«50

Običaj žalostink je del "mrtvaškega kulta» in se še vedno opravlja pri mnogih narodih..$^{51} \mathrm{~V}$ svojih narodopisnih spisih piše o žalostinkah tudi Vuk Karadžić in pravi, da ni še slišal nikjer razen v Paštrovićih, "da bi bile tožbe nespremenljive in v verzih», ampak da ljudstvo žaluje tako kot, pač čuti in vé.52 Glede na to tudi ta zapis iz XVI. stoletja, ki je sicer po vsebini zelo podoben današnjim žalostinkam, ${ }^{33}$ lahko pojmujemo kot besedilo žalostinke, pa čeprav ni verzificiran.

Nemški duhovnik Stephan Gerlach se je mudil v Beli Palanki ravno po neurju, v katerem je izgubilo življenje nekaj žena in otrok. "Okoli

49 Razen obeh omenjenih potopiscev so o pogrebnih običajih pisali: Neznani popotnik iz misije L. Nogarola (1531), Rad JAZU št. 56, 1881, 200; J. Chesneau (1547), Rad JAZU št. 62, 1882, 72; Samardžić R., ibidem, 112-113; J. Gassot (1548), Godišnjica Nikole Čupića št. 49, 1940, 89, Samardžić R., ibidem, 114-115; J. Betzek (1564) Rad JAZU št. 84, 1887, 88-89; P. Lescalopier (1574), Glasnik arhiva i društva arhivista BiH III, 1963, 354-355, Samardžić R., ibidem, 136; A. Wennern (1616), Zbornik za narodni umotvorenija, nauka i knjižnina IV, Sofija 1897, 461.

50 Mijatović đ̌., Pre trista godina, Glasnik SUD št. 36, 1872, 200.

$51 \mathrm{Za}$ najstartejšo zapisano srbsko žalostinko velja žalostinka kralja Milutina za materjo Jeleno, prim. Drobnjaković B., Etnologija naroda Jugoslavije I, Beograd 1963, 162.

52 Karadžic V. S., Etnografski spisi, Beograd 1969, 126.

53 Prim. Djordjevic T., Običaji naroda srpskog, Beograd 1909, 249. 
umrlih so posedale Srbkinje in zalovale po vrsti dve in dve. Potem so prišle druge ženske, se bile po prsih, si pulile lase in praskale lica, da jim je tekla kri na mrliče, katere so poljubljale; tako so delale pri vsakem posameznem mrličuı..54 Davni običaj, da se za umrlim tolče po prsih, praska lica in puli lase, je danes izginil. Zanimiv pa je Gerlachov podatek, da so ženske žalovale po "dve in dve». Pri pogrebnih obredih so sodelovali tudi duhovniki. Po Gerlachovem opisu nje duhovnik, predno je mrliča pokril, polil vsakega po prsih z rdečim vinom in nanj vsul v smeri štirih nebesnih smeri nekoliko zemlje... Nato jih je pokril z deskami in zeleno travo ter $\mathrm{k}$ zglavju pritisnil lesen križ. Duhovnik je tudi napravil nekaj križev nad glavo po grškem običaju in mrmral nekaj besedi, ki so jih drugi ponavljali. $1{ }^{55}$

$\mathrm{V}$ vasici Belica (Bellizza, Belissa) ${ }^{56}$ se je mudila 23. maja 1572 misija Davida Ungnada. "Ko smo prišli semkaj, so skoro vsi moški in ženske šli iz vasi v leseno cerkev, ki je na vzpetini, vsak pa je iz svoje hiše vzel s seboj posodo kuhane pšenice in belega kruha, kar so polagali $\mathrm{v}$ cerkvi na dve dolgi mizi. Nad tema je duhovnik, ob katerem so stali občinske starešine, molil in pel; zatem so ženske, mlade in stare, vsaka z gorečo svečo, šle na pokopališče, ki je ob cerkvi, in na grob svojih krvnih sorodnikov, od katerih jih je mnogo umrlo že pred dvajsetimi leti; zataknile so svečo, se vrgle na grob in $\mathrm{z}$ vso silo klicale in žalovale, nekatere pa so se po obrazu do krvi praskale. Potem ko je to nekaj časa trajalo, so nekatere ženske, ki so imele na glavi vence, tolažile jokajoče in jih peljale nazaj v cerkev, kjer je duhovnik spet molil dolgo molitev, kadil s kadilom, pel in blagoslavljal. Pšeniico in kruh so nesle pred duhovnika, ki je od tega nekaj vzel; zatem je duhovnik spet pel in jih blagoslavljal..157

Splošne, skupne molitve na pokopališču se še vedno opravljajo v mnogih krajih Jugoslavije na dan pogreba in na določene dni v letu. Po Borivoju Drobnjakoviću je to pri pravoslavnih "molitva", pri katoličanih "blagoslov" in pri muslimanih "dova". Eden takih dni v letu, ko se opravljajo obredi za mrtve, so tudi binkoštne zadušnice, v soboto pred krščanskim praznikom binkošti. Ker se je misija $D$. Ungnada mudila $v$ Belici 23. maja po starem koledarju, je skoro gotovo prisostvovala veliki "molitvi«, ki se tudi danes opravlja za pokojne po mnogih vaseh, pa tudi $v$ mestih na dan pred binkoštmi.

Opise zadušnic in praznika sprave ali drugega ponedeljka po veliki noči, ki so podobni opisu iz XVI. stoletja, sta posredovala Vuk Karadžić tri stoletja pozneje v Srpskem rječniku iz leta $1818^{58}$ in učitelj Savatije Grvić v zbranem gradivu o ljudskih običajih v območju Boljevca.59

54 Matković P., ibidem, potopis S. Gerlacha (1573), Rad JAZU št. 116, 1892, $53-54$.

55 Ibidem, 55.

56 Verjetno vas Belica $\mathrm{v}$ bližini Svetozareva na reki Belici, prim. Miličević M. Dj., ibidem, 205. 218.

57 Matković P., ibidem, potovanje D. Ungnada (1572), Rad JAZU št. 112, 1892,

58 Prim. Karadžić V. S., Srpski rječnik, Beograd 1969, stolpec 150 in 192.

59 To gradivo je uredil in izdal T. Djordjević, prim. Običaji naroda srpskog, Beograd 1909, 27-31. 
Posebno zanimiva je prisotnost in udeležba duhovnikov pri opravljanju takšnih poganskih obredov. Nekaj podobnega se je dogajalo tudi na vaških proščenjih, kjer se je začelo takoj po bogoslužju, še v cerkvenem dvorišču, ljudsko veselje. Bližino cerkvenih in poganskih obredov je ostro kritiziral barski nadškof, ko je papeški vizitator prepotoval sredi : XVII. stoletja Crno Goro, Hercegovino in še nekatere kraje, v katerih so živeli ipravoslavni«: "Pri njih (pravoslavnih) se ne zgradi hiše, niti se ne proslavi katerekoli svatbe oziroma se ne vrši nobena javna ali privatna zabava ali svečanost, da ne bi pred začetkom ali po zaključku izvedli ceremonijo petja svetega olja ob mnogokratnem ponavljanju istih besedi, iz katerih sestoji formula poslednjega maziljenja..160

Iz takšne bližnje zveze ljudskih in cerkvenih obredov izhajajo vsekakor mnoge podobnosti ljudskih in cerkvenih napevov. Te podobnosti so se stoletja akumulirale in modificirale tako $\mathrm{v}$ ljudski kot $\mathrm{v}$ cerkveni glasbi. ${ }^{\circ}$

Poleg obredov, ki so posvečeni mrtvim in kjer ljudstvo žaluje in duhovniki pojejo molitve za pokojne, pa je bilo $\mathrm{v}$ teh težkih stoletjih tudi veselje. Takšno ljudsko proslavo je videl Stephan Gerlach na praznik sv. Petra 29. junija, ko je potoval od Pirota proti Nišu. "Kristjani so tega dne praznovali sv. Petra. Imajo cerkev sv. Jurija, v kateri je ravno bilo bogoslužje. Cerkev stoji na vzpetini med ärevjem. Notri je bilo nekaj starih moż, zunaj pa so bile ženske, ki so se brez pobožnosti razgovarjale. Popolỏne (po bogoslužju) so plesala dekleta kolo (hodile so $v$ krogu naokoii) in pele $v$ zborih dve po dver. ${ }^{62}$ To je bilo vaško proslavljanje po izpolnjeni zaobljubi, kot ga ima po Vukovih besedah skoraj vsaka vas v Srbiji.6.3 Domnevamo, da je bilo praznovanje, ki ga opisuje Gerlach, v vasi Ajdanovac blizu Prokuplja, ker je to edini kraj na tem področju, ki je po zgodovinskih virih imel cerkev Sv. Jurija.$^{64} \mathrm{~V}$ tem poročilu je posebno zanimivo "kolo deklet" in njihovo petje "v zborih dve po dve». Žal potopisec potern ne komentira, ali je bilo to petje eno- ali dvoglasno. Ker pa je omenjal ženske, ki žalujejo po "dve in dve«, in so žalostinke najpogosteje enoglasne, ${ }^{65}$ lahko domnevamo, da je bilo to petje deklet enoglasno in so dekleta stala in pela $\mathrm{v}$ parih, verjetno antifonalno. Podoben podatek o petju na vaškem proščenju najdemo v spisih že omenjenega učitelja Savatija Grbića. Ta je konec prejšnjega stoletja zabeležil, da je bila v trgu Boljevac ob proščenju procesija, pri kateri se je vseskozi pelo in to tako, "da so najprej peli fantje vedno po dva in dva in za njimi še dekleta tudi po dve in dve. ${ }^{66}$

Podrobne in zelo zanimive podatke o ljudskem petju in plesu najdemo v potopisu Marc' Antonia Figafette, člana misije nemškega cesarja Mais-

60 Jagić V., Gradja za slovinsku narodnu poeziju, Rad JAZU št. 37, 1876, $49-50$.

61 Prim. Petrović D., Church Elements in Serbian Ritual Songs (v tisku). 62 Matković P., ibid̈em, potopis S. Gerlacha (1573), Rad JAZU št. 116, 1892, 50.

63 Karadžić V. S., ibidem, stolpec 184.

64 Petković V., Pregled crkvenih spomenika kroz povesnicu srpskog naroda, Beograd 1960, 110. V popisu vasi okrožja Prokuplje navaja Milićević vas Asanovac, Kraljevina Srbija, Beograd 1884, 382.

65 Prim. Muzička Enciklopedija II, Zagreb 1963, 259.

66 Djordjević T., Običaji naroda srpskog, Beograd 1909, 213. 
similjana II. Pigafetta je bil, kot večina popotnikov, presenečen nad bogato fokloro in razkošno nošo žensk v okolici Pirota.

Dekleta, katerih nošo opisuje, "so bila lepa. Ker je bila tisti dan nedelja, niso bila zaposlena. Plesala so naokoli in praznovala, vendar so vselej zahtevala denar. Med seboj tekmujoče tri ali štiri pojejo, si odgovarjajo kot zbor, surovo in kmečko petje, dve po dve se drže za roko. Ena je imela na glavi neke vrste klobuk ali kapo, ki je imela vrh $\mathrm{v}$ obliki jadra, ta je oponašala moškega, a druga žensko in ko tako plešejo vselej gredoč druga proti drugi nasprotno. Sprva plešejo zelo počasi, potem pa po malem pospešujejo korak in končno skačejo. Pri tem vselej slede svojemu petju, ki tudi sorazmerno narašča, tako da na koncu vpijejo; sicer pa, kakršen je ples, takšno je tudi petje, divje in surovo.. ${ }^{67}$

Domnevamo, da gre tu za pomladno obredni ples, verjetno za "lazarice», kolednice ob sv. Lazarju. To potrjuje tudi podatek, da se je misija mudila v vasi Klisurica 4. aprila. V Lazarjevem obredu sodeluje še danes šest do osem deklet, ki se delijo na plesalke in pevke. Pevke si stoje nasproti po dve in dve, medtem ko med njimi plesalke plešejo; in ko odpojejo, jim gospodar, kateremu so pele, dâ «jajce, nekoliko volne ali moke, kar ima kdo pač rad in hoče. ${ }^{68}$ Potopiscu ta običaj vsekakor ni bil znan in zato misli, da so si dekleta s plesanjem služila denar.

Podoben opis verjetno istega običaja nam je zapustil Pierre Lescalopier. Mudil se je v Klisurici sedem let za Pigafetto, tudi spomladi, in sicer 27. marca. Prišlo je nekaj deklet, nda bi pred nami izvedla plese in bi jim dali denar. Nakitila so se kot neveste in si pritrdila na glavo krožnik, okrog katerega so bila peresa raznih barv. Plesala so po dve skupaj, druga nasproti drugi, in si počasi izmenjavala mèsta druga z drugo; na koncu so pospešila ritem, skakala in udarjala $\mathrm{z}$ nogami v taktu po zemlji. Spremljali so jih štirje muzikanti, ki so se držali po dva in dva in si odgovarjali $\mathrm{z}$ isto pesmijo. ${ }^{69} \mathrm{Za}$ razliko od svojega predhodnika piše Francoz Lescalopier, da so ples deklet spremljali štiri piskači, ki so se, kot tudi pevke v Pigafettinem opisu, držali po dva in dva in si med seboj odgovarjali, pospešujoč svoje igranje oziroma petje in ples. Antifonalno petje in postopno pospeševanje med izvajanjem je sploh značilnost ljudskega obrednega petja, igranja in plesa, kar še danes lahko slišimo in vidimo v vaseh, ki so ohranila tradicijo.

Kot pravi Jakob Betzek, "je pri Srbih navada, da zaročencu, kadar se ženi, napravi zaročenka venec iz raznovrstnega cvetja, ki ga tudi ona nosi, čez glavo pa ima pajčolan, tako da tistega dne ni videti njenega obraza. Ko zaročenec vodi zaročenko, ji priveže okrog pasu brisačo, če pa je boljši človek, jo ji da v roko, gre naprej in vodi zaročenko za sabo. Ko plešejo, se jih več ulovi med seboj za roke, napravijo krog in plešejo okoli.«70 Kolo je bilo in je ostalo priljubljen ljudski ples v Srbiji, ti veseli svatje 123.

67 Matković P., ibidem, potopis A. Pigafette (1567-68), Rad JAZU št. 100, 1890,

68 Vasiljević M., Narodne melodije leskovačkega kraja, Beograd, 1960, 31.

69 Šamić M., ibidem, 354-355; Samardžić R., ibidem, 136.

70 Matković P., ibidem, potopis J. Betzeka (1564-73), Rad JAZU št. 84, 1887, $88-89$. 
pa so morda plesali ob spremljavi zvončkov, bobnov in piščali, tako kot tisti, ki jih je M. Besolt srečal v Jagoni leta $1584 . .^{71}$

Omenjeni pisci dajejo koristne podatke o ljudskih glasbilih, instrumentalnih skupinah, običajih in obredjih za čas od XVI. do XVIII. stoletja. Podobnost $\mathrm{z}$ običaji in obredi, kot so ti bili $\mathrm{v}$ XIX. stoletju ali so še danes $\mathrm{v}$ posameznih krajih Srbije in Balkanskega polotoka, potrjuje zelo počasno spreminjanje in hkrati zakoreninjeno tradicijo. Ker je glasba neločljivi del ljudskih obredov, lahko domnevamo, da je tudi ona zadržala mnogo podobnosti s petjem in plesom, kakršnega so videli oziroma slišali člani tujih misij na potovanjih skozi balkanske dežele. V prid tej trditvi govori med drugim zapis žalostinke iz leta 1555 , ki je po vsebini podobna današnjim, nadalje antifonalno petje kolednic ob sv. Lazarju in deklet na vaškem proščenju kot tudi obredni ples $\mathrm{v}$ kolu ali $\mathrm{v}$ parih ob instrumentalni spremljavi ali petju $\mathbf{s}$ karakterističnim pospeševanjem ritma. Vse to je ohranjeno do danes $v$ naši glasbeni folklori, vprašanje je samo, kolikšne so bile spremembe $\mathrm{v}$ ustni tradiciji skozi pretekla stoletja.

\section{SUMMARY}

This article is a continuation of the text printed in Arti Musices No. 4, 1973, under the same title. This chapter attempts to discuss information about the folk music and different customs in Balkan countries from the 15th to the 18th century. Important data are found in about two hundred documents - travelogues, daries and the other papers - written by Western delegates during their diplomatic travels through the Balkans.

The information concerns: 1. Folk music instruments and instrumental groups, used on various occasions; seventeen different instruments were mentioned; 2. Folk dances - the Serbian kolo, a soldiers' dance with swords, religious dances of the Muslim dervishi and the popular dance lindjo from the outskirts of Dubrovnik; 3. Different customs which include folk singing and dancing - funeral customs, commemoration of the dead at Pentecost, wedding rituals, spring customs for St. Lazar's Saturday and the Patron Saint's Day of villages.

These documents help to reconstruct a picture of popular and folk music in Serbia during the Turkish occupation. According to descriptions in the various sources discussed, folk music instruments, dances and customs are very similar to those still alive in the Balkan countries. Consequently, it has been possible to reach the conclusion that changes in folk tradition have not been rapla.

71 Prim. str. 6. 